\title{
Comparison of EVA (Economic Value-Added) and Accounting Profit in Explaining Share Returns of Deposit Banks
}

\author{
Derviş Boztosun \\ Erciyes University, Kayseri, Turkey
}

\begin{abstract}
In this study, the success of EVA (Economic Value-Added, a modern performance assessment method) and net profit (a conventional performance assessment method) in explaining the financial performance of corporates was compared. For this purpose, the stock market performance of the shares of deposit banks operating in the banking sector in Turkey was used as the performance indicator of corporates. Then, EVA and the net profit of the period were used to explain the stock market performance of the deposit banks. The research sample was composed of eight deposit banks that have been operating since the year 2005 and whose shares have been publicly traded in stock markets since then and which have available financial tables and share data for this period. The data obtained for this research sample were then subjected to panel data analysis. It was concluded, based on present findings, that EVA was more successful than the net profit of the period in explaining the stock market performance of the deposit banks.
\end{abstract}

Keywords: EVA, net profit of the period, stock market performance, deposit banks

\section{Introduction}

A developed finance sector and a powerful national currency are the principal components of a strong and stable national economy. The significance of the finance sector in the economy basically originates from the role of the sector in the development of a country. The collection and utilization of financial resources, capital accumulation, as well as technological developments significantly influence the economic structure of a country. The finance sector provides support in realizing the collection, assessment, and transfer of information sources at lower costs and also provides significant aids to investors for their efficiency and productivity in financial operations. Therefore, the finance sector makes a positive contribution to economic growth (Aydın, 2006).

In the majority of developing and developed countries and in Turkey, the banking sector constitutes the basis of financial systems. Dondurmacı and Çınar (2014) carried out a study titled "Data mining in the Finance Sector" and used the final quotations of 10 banks. Considering the development of nonbank financial tools, research indicated that Turkey was not able to reach the levels of western countries, but has achieved significant progress in recent years. Nevertheless, the Turkish banking sector still retains its significance in the financial sector of the country (Parasiz, 2011).

Derviş Boztosun, associate professor, Colleges of Applied Sciences, Erciyes University, Kayseri, Turkey.

Correspondence concerning this paper should be addressed to Derviş Boztosun, Erciyes Üniversitesi, Uygulamalı Bilimler Yüksekokulu, Kayseri 38039, Türkiye. 
Since banks have such significance in the financial system, their performance should be realistically determined and assessed. The methods used in the performance assessment of corporates are also used in the performance assessment of banks. In this sense, conventional performance measurement and assessment methods sometimes fall short of reflecting the actual performance of the banks constituting the basis of the financial system. To overcome such deficiencies, the EVA (Economic Value-Added) method developed by the Stern Steward \& Co. Financial Consultancy firm is commonly used in the performance assessment of financial institutions. EVA is defined as the difference between residual profit and alternative costs of the investments of investors with the same risk levels (Stewart, 1991, p. 118). From the company's point of view, EVA is a measure of whether or not the company is able to meet the weighted average cost of capital and is defined as the difference between the after tax return and capital cost (Öztürk, 2004, p. 353).

The stock values of enterprises are a final outcome of their performances. Within the scope of this study, the EVA and accounting profit of deposit banks whose shares are publicly traded and which operate in Turkey were statistically compared to explain their stock market returns.

\section{Literature}

Chen and Dodd (1997) carried out a study about the EVA values and accounting profits of 566 American corporates and concluded that EVA was more effective in explaining stock returns.

Yel (2012) carried out a study to determine the relationships between the current period profits and future stock returns of corporations listed in the Istanbul Stock Exchange (ISE) and used the data of 1,448 corporates between the years 1992-2003. It was observed that as compared to accruals, the current period cash flows of the corporates were more effective on future-period abnormal stock returns.

Avan, Siddique, and Sarwar (2014) carried out a study using the data obtained from 59 corporates listed in Pakistan's KSE100 index and indicated that changes in stock values were influenced by EVA and such effects were found to be significant at $p<0.1$.

Kaya and Öztürk (2015) carried out a study to investigate the relationships between accounting profits and stock quotes. They investigated the relationships between the accounting profits of corporates operating in the ISE Food, Beverage, and Tobacco Sectors for the 2000-2013 period and the stock quotes of these corporations. It was concluded that accounting profits and stock quotes were cointegrated, there was one-way causation from the return on assets representing accounting profits and net profit margin variables to the stock quotes variable and there was two-way causation between the real operating profitability variable and stock quotes variable.

Altaf (2016) carried out a study with 325 corporates in India to determine whether one of the conventional return criteria or EVA was more efficient in explaining market value and indicated that EVA had weak but positive relations with market value.

Cengiz and Özbek Püskül (2016) investigated the relationships between stock the returns and profitability of corporates listed in the Istanbul Stock Exchange and indicated that increases in return on equity and gross profit on sales also increased stock returns and increases in operating profits decreased stock returns. It was also concluded that stock returns could be estimated by using the profitability ratios of the corporates.

\section{Data}

The present study was conducted with deposit banks which constitute the basis of the financial system in Turkey. Information about the domestic, foreign, and public-capital deposit banks whose shares are publicly 
traded in the ISE was obtained from the BAT (The Banks Association of Turkey) web-page. At present, there are 28 deposit banks operating in Turkey. Of these banks,

- three are state-owned,

- nine are privately-owned,

- one was transferred to SDIF (Savings Deposit Insurance Fund),

- 15 are foreign banks.

Following the identification of the banks, those banks whose shares are publicly traded in the ISE were determined through scanning the lists of corporates whose shares are publicly traded from the CMB (Capital Markets Board) web-page. The financial tables of the relevant banks were obtained from the PCP (Public Disclosure Platform) web-page.

Among these banks, those that have been operating since the year 2005 and whose shares have been publicly traded in stock markets since then and which have available financial tables and share data for this period were selected. Although the study covers the period of 2010-2016, for gathering from 2005 onwards is explained in detail in the methodology section. The list of banks complying with these criteria is provided in Table 1.

Table 1

The Deposit Banks Included in This Study

\begin{tabular}{llll}
\hline Bank name & Stock market code & Bank name & Stock market code \\
\hline Akbank T.A.Ş. & AKBNK & Şekerbank T.A.Ş. & SKBNK \\
Denizbank A.Ş. & DENIZ & Türkiye Garanti Bankası A.Ş. & GARAN \\
Finansbank A.Ş. & FINBN & Türkiye İş Bankası A.Ş. & İŞCTR \\
ICBC Turkey Bank A.Ş. & ICBCT & Yapı ve Kredi Bankası A.Ş. & YKBNK \\
\hline
\end{tabular}

\section{Methodology}

In this study, the annual returns of bank shares between the years 2010 and 2016, their "net profit for the period" and "EVA" data were compared. The resultant data bear both cross-section and time-series characteristics. It is more advantageous to treat such data with the panel data approach rather than with conventional approaches (Wooldridge, 2012, p. 448). Therefore, the panel data analysis method was used in this study.

EVA conceptually depends on cost-profit analysis. In this case, it is possible to talk about a value-added creation when the profit from a financial activity is higher than the capital costs (debts + equity costs) expended to achieve this profit.

EVA was calculated as follows (Holler, 2009, p. 56):

$$
\mathrm{EVA}=\text { Invested Equity } \times\left(\mathrm{ROE}-\mathrm{k}_{\mathrm{e}}\right)
$$

Another method for EVA calculation is as follows (Baraz \& Daşbaşı, 2016, p. 523):

$$
\mathrm{EVA}=\mathrm{NOPAT}-\left(\mathrm{k}_{\mathrm{e}} \times \text { Invested Equity }\right)
$$

where,

NOPAT: Net operating profit after taxes

ROE: Return on equity

$\mathrm{k}_{\mathrm{e}}$ : Equity cost 
In this study, Equation (1) is used in EVA calculations. It was found to be advantageous to use this equation to obtain reliable results for the EVA values of banks since banks have quite different financial structures from other corporates.

In this case, initially invested equity, ROE (Return on Equity) and equity cost should be calculated. Information about such calculations is provided below. The calculated values are provided in Tables 4-6.

\section{Calculation of Invested Equity}

The average equity method yields more reliable outcomes in EVA calculations. Therefore, the average equity method is used to determine the equity of relevant banks. In this case, while calculating the equity of a particular year, the amount at the end of the previous year was added to the amount at the end of the relevant year and the sum was then divided by two to determine the average equity of that year (Yazgan, 2014, p. 64).

$$
\text { Average equity }=\left(\text { Equity }_{\text {capital }}+\text { Equity } \text { capital } \mathrm{t}_{\mathrm{t}-1}\right) / 2
$$

\section{Calculation of ROE}

ROE is a ratio indicating the overall performance of a corporate and compares the net profit after taxes of a corporate with the equity invested by shareholders in that corporate. ROE was calculated as follows (Van Horne \& Wachowicz, 1995):

$$
\mathrm{ROE}=\frac{\text { Net profit of the period }}{\text { Equity }}
$$

\section{Calculation of Equity Cost $\left(k_{\mathrm{e}}\right)$}

The "Capital Assets Pricing Model" (CAPM) provided in Equation (5) was used to calculate equity costs. This model is used to measure systematic risk. The following phases are passed through to calculate the equity cost with this model:

(1) The risk-free rate of interest $\left(\mathrm{k}_{\mathrm{rf}}\right)$ is estimated. Treasury bond or state bond interest rates are usually used as the risk-free rate of interest.

(2) The risk coefficient $(\beta)$ of the share is determined.

(3) The market return rate $\left(\mathrm{k}_{\mathrm{m}}\right)$ is determined.

After determining these parameters, the equity cost $\left(\mathrm{k}_{\mathrm{e}}\right)$ is calculated as follows (Aydın, Başar, \& Coşkun, 2015, p. 352):

$$
\mathrm{k}_{\mathrm{e}}=\mathrm{k}_{\mathrm{rf}}+\beta \times\left(\mathrm{k}_{\mathrm{m}}-\mathrm{k}_{\mathrm{rf}}\right)
$$

where,

$\mathrm{k}_{\mathrm{e}}=$ Equity cost

$\mathrm{k}_{\mathrm{rf}}=$ Risk-free rate of interest

$\mathrm{k}_{\mathrm{m}}=$ Expected market return

$\beta=$ Risk coefficient of the share

\section{Risk-Free Rate of Interest}

To determine the risk-free rate of interest to be used in EVA calculations, the annual compound interest rate of a state bond with the greatest trading volume in the "Outright Purchase Sale Market" of the "ISE Debt Instruments Market" on the first operating day of the year was taken as the risk-free interest rate of the relevant 
year (Yazgan, 2014, p. 62). Information about the financial assets represents the annual risk-free interest rates of each year, in other words, information about state bonds is provided in Table 2.

Table 2

Risk-Free Interest Rates of the Relevant Years

\begin{tabular}{llll}
\hline Year & Value-date & Definition & Weighted average compound interest (\%) \\
\hline 2010 & $04 / 01 / 2010$ & TRT031110T10 & 7.82 \\
2011 & $03 / 01 / 2011$ & TRT080812T26 & 7.11 \\
2012 & $03 / 01 / 2012$ & TRT150513T11 & 11.34 \\
2013 & $02 / 01 / 2013$ & TRT240914T15 & 6.11 \\
2014 & $02 / 01 / 2014$ & TRT290114T18 & 7.91 \\
2015 & $02 / 01 / 2015$ & TRT150120T16 & 8.11 \\
2016 & $04 / 01 / 2016$ & TRT140617T17 & 10.99 \\
\hline
\end{tabular}

\section{Beta $(\beta)$}

The Beta coefficient of an asset is calculated by dividing the covariance of the market portfolio of the relevant asset with the variance of the market portfolio (Damodaran, 2002, p. 17). In this case, the Beta coefficient of each year covering the period from 2010-2016 was calculated by dividing the covariance between the monthly returns of the bank share and the ISE 100 index with the variance of the ISE 100 index.

Generally; five-year periods are considered when calculating Beta coefficients and monthly returns are used. The monthly data of the last five years before the year in concern are used. The $\beta$ coefficient was calculated as follows:

$$
\beta_{(t)}=\frac{\operatorname{Cov}\left(\mathrm{r}_{\mathrm{s}_{(\mathrm{t}-5)}} ; \mathrm{r}_{\mathrm{i}(\mathrm{t}-5)}\right)}{\operatorname{Var}\left(\mathrm{r}_{\mathrm{i}(\mathrm{t}-5)}\right)}
$$

$\beta_{\mathrm{t}}=$ The $\beta$ coefficient of the bank at time $t$

$\mathrm{r}_{\mathrm{s}_{(\mathrm{t}-5)}}=$ Monthly return of the share at time $(t-5)$

$\mathrm{r}_{\mathrm{i}_{(\mathrm{t}-5)}}=$ Monthly return of ISE 100 index at time $(t-5)$

The date intervals to be considered for $\beta$ coefficients are provided in Table 3 .

Table 3

Date Intervals for Beta Coefficients

\begin{tabular}{|c|c|c|c|c|c|c|}
\hline \multirow{2}{*}{$\beta$ year $(\mathrm{t})$} & \multicolumn{3}{|c|}{$t$ start } & \multicolumn{3}{|c|}{$t$ end } \\
\hline & Day & Month & Year & Day & Month & Year \\
\hline 2010 & 1 & 3 & 2005 & 12 & 31 & 2009 \\
\hline 2011 & 1 & 2 & 2006 & 12 & 31 & 2010 \\
\hline 2012 & 1 & 1 & 2007 & 12 & 30 & 2011 \\
\hline 2013 & 1 & 1 & 2008 & 12 & 31 & 2012 \\
\hline 2014 & 1 & 1 & 2009 & 12 & 31 & 2013 \\
\hline 2015 & 1 & 1 & 2010 & 12 & 31 & 2014 \\
\hline 2016 & 1 & 3 & 2011 & 12 & 31 & 2015 \\
\hline
\end{tabular}

EVA

The data obtained in the methodology section and EVA values calculated by using Equation (1) are provided in Tables 4-6. 
Table 4

Beta Coefficients and Equity Costs of the Banks

\begin{tabular}{|c|c|c|c|c|c|c|c|c|}
\hline \multirow{9}{*}{ 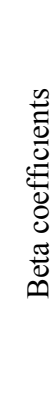 } & Bank/year & 2010 & 2011 & 2012 & 2013 & 2014 & 2015 & 2016 \\
\hline & AKBNK & 1.275103255 & 1.30670798 & 1.285243654 & 1.299563599 & 1.184789036 & 1.196297633 & 1.242505787 \\
\hline & DENIZ & 0.540816924 & 0.304776962 & 0.363136992 & 0.327550839 & 0.055979547 & 0.172116333 & 0.250471896 \\
\hline & FINBN & 0.690395284 & 0.534981873 & 0.55415056 & 0.553916748 & 0.490220434 & 0.397322901 & 0.656344134 \\
\hline & GARAN & 1.49110197 & 1.586791478 & 1.540927644 & 1.483962091 & 1.352075061 & 1.281489028 & 1.27737258 \\
\hline & ICBC & 1.561523955 & 1.372896461 & 1.272842818 & 1.228923271 & 1.074854919 & 1.017730355 & 0.975598909 \\
\hline & ISCTR & 1.165255316 & 1.25268945 & 1.188146377 & 1.20449227 & 1.247450193 & 1.298302353 & 1.215100293 \\
\hline & SKBNK & 1.498096874 & 1.372695191 & 1.336677222 & 1.344972151 & 1.212617752 & 0.762964952 & 0.706288243 \\
\hline & YKBNK & 1.089794547 & 1.119787871 & 1.126096853 & 1.171768405 & 1.332604138 & 1.333279738 & 1.408457215 \\
\hline \multirow{2}{*}{\multicolumn{2}{|c|}{$\begin{array}{l}\text { Risk-free rate of interest } \\
\text { Market risk premium }\end{array}$}} & 0.0782 & 0.0711 & 0.1134 & 0.0611 & 0.0791 & 0.0811 & 0.1099 \\
\hline & & 0.016455951 & 0.016455951 & 0.016455951 & 0.016455951 & 0.016455951 & 0.016455951 & 0.016455951 \\
\hline \multirow{9}{*}{ 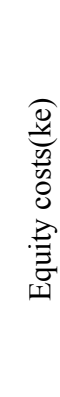 } & Bank/year & 2010 & 2011 & 2012 & 2013 & 2014 & 2015 & 2016 \\
\hline & AKBNK & 0.099183037 & 0.092603123 & 0.134549907 & 0.082485555 & 0.098596831 & 0.100786215 & 0.130346615 \\
\hline & DENIZ & 0.087099657 & 0.076115395 & 0.119375765 & 0.066490161 & 0.080021197 & 0.083932338 & 0.114021753 \\
\hline & FINBN & 0.089561111 & 0.079903636 & 0.122519075 & 0.070215227 & 0.087167044 & 0.087638326 & 0.120700767 \\
\hline & GARAN & 0.102737501 & 0.097212163 & 0.13875743 & 0.085520008 & 0.101349681 & 0.102188121 & 0.130920381 \\
\hline & ICBC & 0.103896362 & 0.093692317 & 0.134345839 & 0.081323101 & 0.09678776 & 0.097847721 & 0.125954408 \\
\hline & ISCTR & 0.097375385 & 0.091714196 & 0.132952079 & 0.080921066 & 0.099627979 & 0.1024648 & 0.129895631 \\
\hline & SKBNK & 0.102852609 & 0.093689005 & 0.135396295 & 0.083232796 & 0.099054779 & 0.093655314 & 0.121522645 \\
\hline & YKBNK & 0.096133606 & 0.089527175 & 0.131930995 & 0.080382564 & 0.101029269 & 0.103040386 & 0.133077503 \\
\hline
\end{tabular}


Table 5

Average Equity of the Banks and Net Profit for the Period

\begin{tabular}{|c|c|c|c|c|c|c|c|c|}
\hline \multirow{9}{*}{ 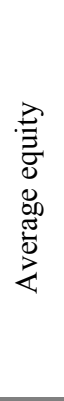 } & Bank/year & 2010 & 2011 & 2012 & 2013 & 2014 & 2015 & 2016 \\
\hline & AKBNK & も17,947,594.00 & も18,131,379.00 & $\ddagger_{22,475,768.00}$ & $\ddagger_{22}, 134,979.00$ & $\ddagger_{2} 6,140,044.00$ & $\ddagger_{28,014,891.00}$ & $€ 32,492,267.00$ \\
\hline & DENIZ & $€ 3,659,205.00$ & $€ 4,641,463.00$ & $も 5,664,624.00$ & $€ 6,088,369.00$ & $\ddagger_{7}, 161,184.00$ & $€ 8,294,197.00$ & ६10,590,098.00 \\
\hline & FINBN & $€ 5,386,467.00$ & $€ 5,911,323.00$ & も7,412,284.00 & 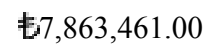 & $€ 8,797,614.00$ & Ł $9,405,485.00$ & €10,303,779.00 \\
\hline & GARAN & も16,675,418.00 & も17,899,787.00 & $€ 21,641,185.00$ & $€ 23,016,169.00$ & $\ddagger_{26,661,015.00}$ & $€ 31,203,756.00$ & €35,795,907.00 \\
\hline & ICBC & $も 496,544.00$ & $も 517,790.00$ & $€ 574,901.00$ & $€ 604,308.00$ & $も 620,136.00$ & $€ 597,194.00$ & $も 607,007.00$ \\
\hline & ISCTR & も17,013,804.00 & も17,921,364.00 & $\ddagger_{22,719,045.00}$ & $€ 23,579,117.00$ & $€ 29,311,067.00$ & $€ 32,034,990.00$ & €35,960,981.00 \\
\hline & SKBNK & $\hbar_{1,400,497.00}$ & $\hbar_{1,462,137.00}$ & も1,824,741.00 & $\hbar_{2}, 055,448.00$ & $€_{2,391,813.00}$ & $€ 2,526,942.00$ & $€ 2,532,793.00$ \\
\hline & YKBNK & も10,745,769.00 & も12,635,234.00 & も16,039,538.00 & も18,285,510.00 & $€_{2} 0,213,705.00$ & $€_{2} 3,086,402.00$ & ₹26,121,153.00 \\
\hline \multirow{9}{*}{ 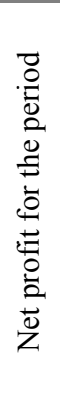 } & Bank/year & 2010 & 2011 & 2012 & 2013 & 2014 & 2015 & 2016 \\
\hline & $\overline{\mathrm{AKBNK}}$ & $€ 33,008,809.00$ & $€ 2,536,375.00$ & $€ 3,004,910.00$ & $€ 3,077,177.00$ & $€ 3,378,639.00$ & $€ 3,229,357.00$ & $€ 4,854,168.00$ \\
\hline & DENIZ & も614,240.00 & も1,061,546.00 & $€ 717,427.00$ & $\ddagger_{1,011,230.00}$ & も937,409.00 & $€ 858,403.00$ & $\ddagger_{1}, 400,027.00$ \\
\hline & FINBN & も922,922.00 & €883,731.00 & も1,103,630.00 & $\hbar_{7} 76,151.00$ & も900,688.00 & $€ 664,350.00$ & $\ddagger_{1}, 236,405.00$ \\
\hline & GARAN & $\hbar_{3}, 363,845.00$ & $\hbar_{3}, 326,299.00$ & $€ 3,331,073.00$ & $€ 3,314,434.00$ & $€ 3,647,404.00$ & $€ 3,580,901.00$ & $€ 5,105,291.00$ \\
\hline & ICBC & €20,042.00 & も24,626.00 & $€ 26,058.00$ & ŁA5,316.00 & も12,760.00 & も13,542.00 & も18,749.00 \\
\hline & ISCTR & $\hbar_{2}, 982,210.00$ & $\hbar_{2}, 667,487.00$ & $€ 3,310,307.00$ & $\hbar_{3}, 163,365.00$ & $€ 3,382,442.00$ & $€ 3,082,691.00$ & $€ 4,701,206.00$ \\
\hline & SKBNK & $\ddagger_{170,247.00}$ & $\ddagger_{118,044.00}$ & $\ddagger_{240,302.00}$ & $\ddagger_{2} 10,216.00$ & $\hbar_{223,969.00}$ & $\hbar_{102,649.00}$ & $\ddagger_{125,194.00}$ \\
\hline & YKBNK & $\hbar_{2,248,031.00}$ & $\hbar_{2}, 284,704.00$ & $€_{2,087,673.00}$ & $\hbar_{3}, 658,952.00$ & $€_{2,056,015.00}$ & も1,908,683.00 & $€_{2}, 932,795.00$ \\
\hline
\end{tabular}


Table 6

ROE, EVA and Share Annual Returns of the Banks

\begin{tabular}{|c|c|c|c|c|c|c|c|c|}
\hline \multirow{9}{*}{ 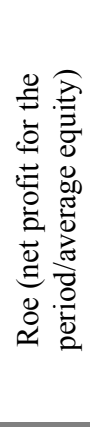 } & Bank/year & 2010 & 2011 & 2012 & 2013 & 2014 & 2015 & 2016 \\
\hline & AKBNK & 0.167644142 & 0.139888698 & 0.133695543 & 0.139018745 & 0.129251466 & 0.115272874 & 0.149394562 \\
\hline & DENIZ & 0.167861598 & 0.228709353 & 0.126650418 & 0.166092101 & 0.130901398 & 0.103494407 & 0.132201515 \\
\hline & FINBN & 0.171340881 & 0.149498006 & 0.148892028 & 0.09488837 & 0.102378668 & 0.070634316 & 0.119995295 \\
\hline & GARAN & 0.201724778 & 0.185828971 & 0.153922856 & 0.144004591 & 0.136806644 & 0.114758653 & 0.1426222 \\
\hline & ICBC & 0.040362989 & 0.047559822 & 0.045326065 & 0.074988251 & 0.020576132 & -0.022676048 & 0.030887617 \\
\hline & ISCTR & 0.175281789 & 0.148843972 & 0.145706257 & 0.134159604 & 0.115398119 & 0.096228873 & 0.13073075 \\
\hline & SKBNK & 0.121561846 & 0.080733885 & 0.131691018 & 0.102272595 & 0.093639846 & 0.040621827 & 0.049429227 \\
\hline & YKBNK & 0.209201501 & 0.180820078 & 0.130157926 & 0.200101173 & 0.101713911 & 0.082675637 & 0.112276629 \\
\hline \multirow{9}{*}{ 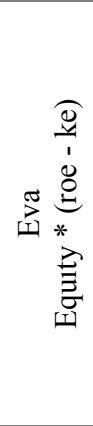 } & Bank/year & 2010 & 2011 & 2012 & 2013 & 2014 & 2015 & 2016 \\
\hline & AKBNK & 1228712.122 & 857352.6854 & -19202.48996 & 1251360.969 & 801313.5116 & 405842.1603 & 618910.9969 \\
\hline & DENIZ & 295524.5 & 708259.2113 & 41208.1788 & 606413.3673 & 364362.4866 & 162251.6541 & 192525.4586 \\
\hline & FINBN & 440504.0306 & 411394.8012 & 195483.8239 & 194016.3013 & 133825.9976 & -159930.963 & -7269.028471 \\
\hline & GARAN & 1650654.223 & 1586221.987 & 328197.7858 & 1346091.05 & 945318.6298 & 392247.81 & 418877.2241 \\
\hline & ICBC & -31547.11516 & -23886.94489 & -51177.55734 & -3828.20073 & -47261.57438 & -71976.07192 & -57706.20735 \\
\hline & ISCTR & 1325484.292 & 1023843.502 & 289762.7398 & 1255317.717 & 462239.6187 & -199767.8475 & 30031.67829 \\
\hline & SKBNK & 26202.22964 & -18942.16076 & -6761.170917 & 39135.31582 & -12951.50698 & -134012.5465 & -182597.7042 \\
\hline & YKBNK & 1215001.478 & 1153507.2 & -28439.20484 & 2189115.828 & 13839.16751 & -470148.7795 & -543342.8208 \\
\hline \multirow{9}{*}{ 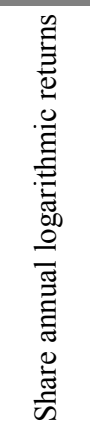 } & Banka / y1l & 2010 & 2011 & 2012 & 2013 & 2014 & 2015 & 2016 \\
\hline & AKBNK & -0.107107241 & -0.365934269 & 0.37634771 & -0.290662701 & 0.27772412 & -0.260065413 & 0.155540534 \\
\hline & DENIZ & 0.425943639 & 0.098159764 & -0.097328344 & -0.36500032 & 0.006557401 & -0.408792898 & 0.841992808 \\
\hline & FINBN & -0.044680971 & -0.306863131 & -0.167702103 & -0.311436158 & 0.177771663 & 0.61146915 & 0.191268343 \\
\hline & GARAN & 0.200386564 & -0.301986061 & 0.440633568 & -0.325741634 & 0.325912476 & -0.278865228 & 0.129639649 \\
\hline & ICBC & 0.009302393 & -0.582395816 & 0.345501643 & 0.140229341 & 0.45731847 & 0.33341179 & -0.377134601 \\
\hline & ISCTR & -0.135801541 & -0.536475703 & 0.612357926 & -0.303682414 & 0.384179901 & -0.333361814 & 0.291762521 \\
\hline & SKBNK & -0.392194771 & -0.687576136 & 0.715620036 & 0.101096117 & -0.117783036 & -0.085522173 & -0.251314428 \\
\hline & YKBNK & 0.393195016 & -0.615888697 & 0.655406853 & -0.357749635 & 0.295208622 & -0.39834764 & 0.031832927 \\
\hline
\end{tabular}




\section{Implementation of Panel Data Analysis}

Econometric data are usually defined as cross section and time series. The union of these two data types is defined as panel data (Kutlar, 2017, p. 11). The stock market index returns of deposit bank shares were used as the independent variable and the bank EVA values and accounting profit data were used as the explanatory variable. The target herein is to determine whether EVA or accounting profit was more effective in explaining the stock market returns of bank shares.

Initially variable stability should be tested to decide which method should be used for the analysis of relationships between the variables (Saldanlı \& Aydın, 2016, p. 5). The first difference in the unstable data was taken initially and the following hypotheses were created for stability tests:

$\mathrm{H}_{0}$ : There is a unit root in the panel data set (Series are not stable)

$\mathrm{H}_{1}$ : There is no unit root in the panel data set (Series are stable)

Stability test results are provided in Table 7.

Table 7

Panel Unit Root Test Results

\begin{tabular}{lllllll}
\hline & \multicolumn{3}{c}{ Index return } & \multicolumn{2}{c}{ EVA } & \multicolumn{2}{c}{ Net profit of the period } \\
\hline Method & Test statistics & $P$ value & Test statistics & $P$ value & Test statistics & $P$ value \\
\hline Levin, Lin \& Chu $t$ & -16.3016 & 0.0000 & -10.9351 & 0.0000 & -6.19525 & 0.0000 \\
Pesaran \& Shin W-stat & -6.35359 & 0.0000 & -3.37066 & 0.0004 & -2.26750 & 0.0117 \\
Fisher Chi-square & 63.7653 & 0.000 & 43.9574 & 0.0002 & 34.4276 & 0.0048 \\
\hline
\end{tabular}

Since the $p$ values for the test statistics calculated by all methods were less than 0.05 , the null hypothesis was rejected. This means that there were not any unit roots in the series and thus the series were stable.

Following the identification of stability, the relationships among the variables were analyzed with panel regression models. There are three models, of which one should be preferred.

The first of these three models is the Pooled Regression model. These models pool all observations together and run the regression model, neglecting the cross-section and time-series nature of data. However, the major problem with this model is that it does not distinguish between the various deposit banks that we have. This means that, by combining eight deposit banks through pooling, we deny the heterogeneity or individuality that may exist among the eight deposit banks.

The second model is the Fixed Effect or LSDV model. This model allows for heterogeneity or individuality among the eight deposit banks by allowing each to have its own intercept value.

The third model is the Random Effect model. Here, the eight deposit banks have a common mean value for the intercept.

All three models were used in this study. In the first model (Model A), the effects of EVA and net profit of the period on stock market returns of the shares were investigated for the same period. In the second model (Model B), the one-lag values of EVA and net profit of the period were included in the model. In the last model (Model C), the two-lag values of EVA and net profit of the period were included in the model.

Now we apply the Hausman Test to check which model (Fixed Effect or Random Effect) is most suitable. The hypotheses are given below.

$\mathrm{H}_{0}$ : The Random Effect model is appropriate 
$\mathrm{H}_{1}$ : The Fixed Effect model is appropriate

The Hausman test results are provided in Table 8.

Table 8

Hausman Test Results

\begin{tabular}{llll}
\hline & Model A & Model B & Model C \\
\hline Chi-Sq. & 2.962711 & 0.526826 & 7.103260 \\
Prob. & 0.2273 & 0.9708 & 0.3114 \\
\hline
\end{tabular}

The probability values were $0.2273,0.9708$, and 0.3114 which are all greater than 0.05 , meaning that the null hypothesis of these three models should be rejected. This means that the Random Effect model was the most appropriate of the three models.

Following the decision to use the Random Effect model, the test results for all three models created are provided in Table 9.

Table 9

Random Effect Panel Test Results

\begin{tabular}{|c|c|c|c|c|c|c|c|}
\hline & & EVA & $\operatorname{EVA}(-1)$ & $\operatorname{EVA}(-2)$ & Profit & Profit(-1) & Profit(-2) \\
\hline \multirow{4}{*}{ 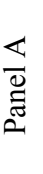 } & t-Stat & -5.355328 & - & - & 3.751580 & - & - \\
\hline & t-Prob & 0.0000 & - & - & 0.0005 & - & - \\
\hline & F-Stat & 16.56097 & & & & & \\
\hline & F-Prob & 0.0000 & & & & & \\
\hline \multirow{4}{*}{ 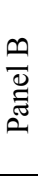 } & t-Stat & -2.702432 & 2.317381 & - & 2.689121 & -0.941346 & - \\
\hline & t-Prob & 0.0105 & 0.0265 & - & 0.0109 & 0.0353 & - \\
\hline & F-Stat & 9.494328 & & & & & \\
\hline & F-Prob & 0.0000 & & & & & \\
\hline \multirow{4}{*}{ 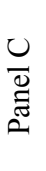 } & t-Stat & -2.811872 & 1.014971 & -1.749701 & 1.743401 & -1.109597 & 0.262759 \\
\hline & t-Prob & 0.2006 & 0.3198 & 0.0936 & 0.0936 & 0.2777 & 0.7949 \\
\hline & F-Stat & 9.198907 & & & & & \\
\hline & F-Prob & 0.0000 & & & & & \\
\hline
\end{tabular}

\section{Conclusion}

In this study, the EVA and net profit of the period were compared to explain the share returns of the deposit banks, in other words to explain the financial performance of the banks. The basic target was to check whether EVA was better than conventional methods in revealing corporate performance. For this purpose, data about deposit banks which constitute the basis of the financial system in Turkey were used. The EVA and annual net profits of eight deposit banks whose shares are publicly traded and which operate in Turkey were calculated for the years between 2005 and 2016, and their significance in explaining the annual returns of bank shares in the ISE was assessed. Resultant data were analyzed with the panel data analysis method and the results are provided in Table 9.

In panel A of the table, the results about the performance of the values of explanatory variables at time $t$ in explaining the value of the independent variable at time $t$ are provided. The lower $p$ value of EVA (0.000) compared to that of net profit (0.0005) indicated that EVA was a stronger explanatory variable. In panel B of the table, the results about the performance of the values of the explanatory variables at time $t$ and $t-1$ in explaining the value of the independent variable at time $t$ are provided. In this model, the $p$ value of 
$\operatorname{EVA}(0.0105)$ was lower than that of net profit (0.0109) and the $p$ value of EVA at time $t$-1 (EVA(-1)) (0.0265) was also lower than that of net profit at time $t$-1 (PROFIT(-1)) (0.0353).

It was concluded, based on current findings, that in Model A and Model B, EVA was stronger than net profit in explaining the share performance of the deposit banks. In model $\mathrm{C}$, the results were not found to be significant at 0.05 significance level.

\section{References}

Altaf, N. (2016). Economic value added or earnings: What explains market value in indian firms? Future Business Journal, 2(2), 152-166.

Awan, A. G., Siddique, K., \& Sarwar, G. (2014). The effect of economic value added on stock return: Evidence from selected companies of Karachi stock exchange. Research Journal of Finance and Accounting, 5(23), 140-152.

Aydın, N. (2006). Bankacılık Uygulamaları. Eskişehir: Anadolu Üniversitesi.

Aydın, N., Başar, M., \& Coşkun, M. (2015). Finansal Yönetim (2. Baskı). Ankara: Detay Yayıncılık.

Cengiz, H., \& Özbek Püskül, A. S. (2016). Hisse Senedi Getirileri ve Kârlılık Arasındaki İlişki: Borsa İstanbul Endeksinde İşlem Gören İşletmelerin Analizi, Yalova Sosyal Bilimler Dergisi, 7(12), 295-306.

Chen, S., \& Dodd, J. L. (1997). Economic value added (EVA $\left.{ }^{\mathrm{TM}}\right)$ : An empirical examination of a new corporate performance measure. Journal of Managerial Issues, 318-333.

Damodaran, A. (2002). Investment valuation: Tools and techniques for determining the value of any asset. New York: Wiley John Wiley \& Sons, Inc.

Dondurmac1, G., \& Çınar, M. (2014). Finans Sektöründe Veri Madenciliği Uygulaması. ASOS Journal, 2/1, $258-271$.

Holler, A. (2009). New metrics for value-based management: Enhancement of performance measurement and empirical evidence on value-relevance. Weisbaden (Germany): Springer Gabler.

Kaya, A., \& Öztürk, M. (2015), Muhasebe Kârları İle Hisse Senedi Fiyatları Arasındaki İlişki: BİST Firmaları Üzerine Bir Uygulama. Muhasebe ve Finansman Dergisi, 67, 37-54.

Kutlar, A. (2017). Adım Adım EViews ile Panel Veri Ekonometrisi Uygulamaları. Kocaeli: Umuttepe Yayınları.

Öztürk, M. B. (2004). Finansal Performansın Ölçülmesinde Alternatif Bir Yöntem: "Ekonomik Katma Değer". Atatürk Üniversitesi İktisadi ve İdari Bilimler Dergisi, 18(3-4), 351-368.

Parasız, İ. (2011). Türkiye'de ve Dünyada Bankacılık. Bursa: Ezgi Kitabevi.

Saldanlı, A., \& Aydın, M. (2016). Bankacılık Sektöründe Karlılı̆̆ı Etkileyen Faktörlerin Panel Veri Analizi İle İncelenmesi: Türkiye Örneği. Ekonometri Ve İstatistik E-Dergisi, 24, 1-9.

Stewart, G. B. (1991). The quest for value: A guide for senior managers (1st ed.). New York: Harper Collins Publishers.

Van Horne, J., \& Wachowicz, J. M. (1995). Fundamentals of financial management. New Jersey: Prentice Hall International Editions.

Wooldridge, J. M. (2012). Introductory econometrics: A modern approach. Ohio: South-Western Cengage Learning.

Yazgan, G. (2014). Performans Ölçüm Aracı Olarak Ekonomik Katma Değer: BİST'de İşlem Gören Bankalara Uygulanması (Yayımlanmamış Doktora Tezi). Ankara: T.C. Gazi Üniversitesi Sosyal Bilimler Enstitüsü İşletme Anabilim Dalı Finansman Bilim Dal1.

Yel, T. (2012), Kar Kalitesi ve Hisse Senedi Getirileri Arasındaki İlişkinin İmkb’de Test Edilmesi. Uluslararası Yönetim İktisat ve Işletme Dergisi, 8(16), 119-135. 